NOTE

\title{
Detection of infectious hematopoietic necrosis virus in rainbow trout Oncorhynchus mykiss from an outbreak in Taiwan by serological and polymerase chain reaction assays
}

\author{
Way-Shyan Wang*, Jainn-Shyan Lee, Mong-Teng Shieh, Yea-Ling Wi, Chien-Jin Huang, \\ Maw-Sheng Chien
}

Department of Veterinary Medicine, National Chung Hsing University, Taichung, Taiwan 400, ROC

\begin{abstract}
In Taiwan, 3 viral isolates were made from a disease outbreak in rainbow trout Oncorhynchus mykiss cultured in ponds during the period from November 1994 to February 1995. Polymerase chain reaction (PCR) was used for identification of the isolates. The results revealed that a specific 252 bp viral nucleotide was amplified by using infectious hematopoietic necrosis virus (IHNV) specific primers. At the same time, several IHNV monoclonal antibodies (MAbs), and an IHNV specific rabbit polyclonal antibody were used to confirm the results of the PCR assay. The results of the above assays indicated that all isolates were IHNV.
\end{abstract}

KEY WORDS: IHNV $\cdot$ PCR $\cdot$ MAb Taiwan - Fish - Virus

Infectious hematopoietic necrosis (IHN) occurs worldwide and has been found in North America, Japan, Taiwan, France, and Italy (Sano 1976, Chen et al. 1985, Baudin-Laurencin 1987, Bovo et al. 1987, Wolf 1988). The causative agent, IHN virus, is believed to have spread from North America to other countries by the shipment of infected fish or eggs (Amend et al. 1975, Mulcahy et al. 1985). Although IHN virus (IHNV) infection was reported in Taiwan $10 \mathrm{yr}$ ago (Chen et al. 1985), it was not reported after that until a disease outbreak occurred in rainbow trout ponds in the central part of Taiwan during November 1994 to February 1995. The infected fry, about 2 to $3 \mathrm{~cm}$ in length, were lethargic and anorexic. Most of them lay on the bottom of ponds for several days before dying. There were no significant external or internal clinical signs, except a dark appearance, found in infected and dying fry. The morbidity and mortality of the outbreak were

-E-mail: 211wswang@vax9k.nchu.edu.tw
$90 \%(22000 / 25000)$ and 95\% (21000/22000), respectively.

To date, there are no effective therapeutics for this viral disease so the only available control measure is avoidance. It is time-consuming and expensive to detect virus in infected fish by cell culture techniques and/or serological tests (Hsu \& Leong 1985, Nicholson 1993). Recently, a new diagnostic technique, the polymerase chain reaction (PCR) assay, has been developed for many animal and human diseases, and the specificity and sensitivity of this method for identifying IHNV has already been demonstrated (Arakawa et al. 1990). The aim of this study was to use this method to identify the IHNV isolates made from infected cultured rainbow trout.

Materials and methods. Pathological examination: Liver, kidney, spleen, and gill tissues taken from infected and dying fry were fixed in $10 \%$ neutralbuffered formalin $(\mathrm{v} / \mathrm{v})$, then dehydrated, embedded, sectioned, and stained with hematoxylin and eosin. The slides were examined by light microscopy.

Viral isolation: The method for virus isolation was a modification of the method described by Nicholson (1989). The CHSE-214 cell line was used for virus isolation attempts from the tissue extracts of infected and dying rainbow trout fry. All cell culture flasks inoculated with tissue extracts were incubated at $18^{\circ} \mathrm{C}$, examined daily for cytopathic effect (CPE) and the $\mathrm{TCID}_{50} \mathrm{ml}^{-1}$ of the isolates determined after $6 \mathrm{~d}$ incubation.

Immunodot assay: The immunodot assay used was a modification of the procedures described by CaswellReno et al. (1989) and Jørgensen et al. (1991). The positive control (IHNV) and the negative control virus 
(infectious pancreatic necrosis virus; IPNV) were kindly supplied by Dr B. L. Nicholson. Monoclonal antibodies (MAb 1H8, MAb 3B12, and MAb 5H2) against IHNV (Huang et al. 1994), a polyclonal rabbit antiserum for IHNV (NI 43) supplied by Dr J. R. Winton, and a MAb for IPNV, (MAb AS1) donated by Dr B. L. Nicholson were used for this assay.

Primers: The specific primers for IHNV were synthesized as the published primers (Arakawa et al. 1990). The first primer, located on 319-338 of the open reading frame (ORF) (sense orientation) of the $\mathrm{N}$ gene, 5'-TTCGCAGATCCCAACAACAA-3', was 20 nucleotides long. The second primer, located on 570-552 of the ORF (antisense orientation) of the $\mathrm{N}$ gene, 5'CTTGGTGAGCTTCTGTCCA-3', was 19 nucleotides in length.

Polymerase chain reaction: The thermal cycle reaction method was a modification of the method described by Arakawa et al. (1990). The isolates and the IPN (negative control) viruses used were prepared in CHSE-214 cells. Approximately $10^{7} \mathrm{TCID}_{50}$ of virus contained in $500 \mu \mathrm{l}$ were prepared for copying into cDNA by a reverse transcriptase (BRL, Gaithersburg, $\mathrm{MD}, \mathrm{USA}$ ) reaction at $50^{\circ} \mathrm{C}$ for $20 \mathrm{~min}$. Subsequently, the above reaction mixtures received $2.5 \mathrm{U}$ of $\mathrm{T}_{\mathrm{aq}}$ polymerase (BRL) for 25 cycles in an automatic thermal cycler (PC 700; ASTEC Co, Fukung, Japan) programmed for $1 \mathrm{~min}$ at $95^{\circ} \mathrm{C}, 30 \mathrm{~s}$ at $40^{\circ} \mathrm{C}$, and $2 \mathrm{~min}$ at $72^{\circ} \mathrm{C}$. The amplified product was analyzed for size following electrophoresis $(80 \mathrm{~V}, 1.5 \mathrm{~h})$ in $1.5 \%$ agarose gels and staining with ethidium bromide.

Results and discussion. Light microscope examination of histological sections showed no significant pathological changes in the infected fish samples examined .

Three viral isolates were made in cell cultures from fry dying in 3 different culture ponds. After incubation at $18^{\circ} \mathrm{C}$ for 5 to $6 \mathrm{~d}$, the CPE typical for IHNV in CHSE214 cells was found. The titers of the isolates, NCH1, $\mathrm{NCH} 2$, and $\mathrm{NCH} 3$, were in the range of $10^{7}$ to $10^{8}$ $\mathrm{TCID}_{50} \mathrm{ml}^{-1}$

About $10^{4}$ to $10^{5} \mathrm{TCID}_{50}$ of each isolate and similar amounts of each control virus (IHNV and IPNV) were used for the immunodot assay. The results indicated the isolates were IHNV, not IPNV (Table 1)

The specific viral nucleotide product band of IHNV, $252 \mathrm{bp}$, was amplified from all isolates by the PCR (Fig. 1)

In this case, no obvious external or internal clinical signs of disease were seen, except the dark appearance found in infected and dying fry. Usually, infectious hematopoietic necrosis virus causes degenerative and necrotic changes in the kidney, hematopoietic tissues, pancreas, gastrointestinal tract, and adrenal cortex of infected fish (Wolf 1988). However, light micro-

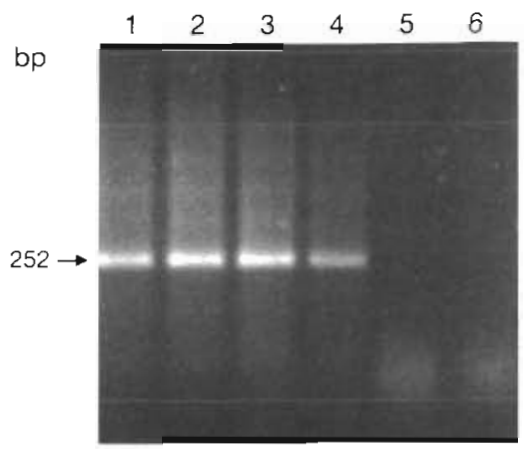

Fig. 1. Amplified viral products from isolates by thermal cycle reaction were analyzed on an ethidium bromide-stained $1.5 \%$ agarose gel. Lane 1. NCH1 isolate; lane 2: NCH2 isolate, lane 3: NCH3 isolate; lane 4: IHNV positive control virus; lane 5: aquatic animal birnavirus; lane 6: uninfected CHSE-214 cells

scopic examination of tissue samples of the infected fry did not show significant pathological changes. The reason for this might be that in these very small and highly susceptible fry the infection was of the peracute type and proceeded at a rate without enough time to produce pathological changes. Thus, only a darkened coloration was found in infected and dying fry

Several techniques including the neutralization (Hatttenberger-Baudouy et al. 1989, Jørgensen et al. 1991), fluorescent antibody, and enzyme-linked immunosorbent assay (ELISA) (Dixon \& Hill 1984, Way \& Dixon 1988, Jørgensen et al. 1991) methods have been developed for detecting IHNV in fish. A new biotechnique, $\mathrm{PCR}$, was utilized to detect viral particles in fish tissue. The PCR method for IHNV identification was reported to be very specific and sensitive, detecting about $4 \times 10^{2}$ plaque forming units (PFU) $\mathrm{ml}^{-1}$ in kidney/spleen extracts (Arakawa et al. 1990). Compared to cell culture and serologic techniques, the PCR method was quicker and cheaper for detecting pathogens from infected fish tissue extracts (Arakawa et al. 1990) and was useful for screening virus-carrying fish in ponds.

Table 1. Identification of isolates from rainbow troul as IHNV by immunodot assay. + : positive reaction; -: negative reaction

\begin{tabular}{|c|c|c|c|c|c|}
\hline \multirow[t]{2}{*}{ Virus } & \multicolumn{3}{|c|}{ IHNV MAbs } & \multirow{2}{*}{$\begin{array}{c}\text { IHNV } \\
\text { polyclonal } \\
\text { Ni43 }\end{array}$} & \multirow{2}{*}{$\begin{array}{l}\text { IPNV } \\
\text { Mab } \\
\text { AS1 }\end{array}$} \\
\hline & $1 \mathrm{H} 8$ & $3 \mathrm{~B} 12$ & $5 \mathrm{H} 2$ & & \\
\hline $\mathrm{NCH} 1$ & + & + & + & + & - \\
\hline $\mathrm{NCH} 2$ & + & + & + & + & - \\
\hline $\mathrm{NCH} 3$ & + & + & + & + & - \\
\hline IHNV & + & + & + & + & - \\
\hline IPNV & - & - & - & - & + \\
\hline CHSE-214 & - & - & - & - & - \\
\hline
\end{tabular}


During the past $10 \mathrm{yr}$, there were no case reports of IHN viral disease in Taiwan. During these years, the rainbow trout culture industry has become popular in the high mountain area so that numerous eyed eggs have been imported from North America, Japan, and other countries every year, creating many chances for IHNV to be transmitted into Taiwan. However, the origin of IHNV is still unknown and it is possible that it was endemic in the ponds. Whatever the source, IHNV will remain important for aquaculture in Taiwan and will need to be continually monitored in the future.

Acknowledgements. The authors thank Dr J. R. Winton and Dr B. L. Nicholson for supplying the monoclonal antibodies and viruses used in this study.

\section{LITERATURE CITED}

Amend DF (1975) Detection and transmission of infectious hematopoietic necrosis in rainbow trout. J Wildlife Dis 11: $471-478$

Arakawa CK, Deering RE, Higman $\mathrm{KH}$, Oshima $\mathrm{KH}$, O'Hara PJ, Winton JR (1990) Polymerase chain reaction (PCR) amplification of a nucleoprotein gene sequence of infectious hematopoietic necrosis virus. Dis Aquat Org 8: $165-170$

Baudin-Laurencin F (1987) IHN in France. Bull Eur Ass Fish Pathol 7:104

Bovo G, Giorgetti G, Jørgensen PEV, Olesen NJ (1987) Infectious hematopoietic necrosis: first detection in Italy. Bull Eur Ass Fish Patho] 7:24

Caswell-Reno P, Lipipun L, Reno PW, Nicholson BL (1989) Utilization of a group-reactive and other monoclonal antibodies in an enzyme immunodot assay for identification and presumptive serotyping of aquatic birnaviruses. J Clin Microbiol 27:1924-1929

Responsible Subject Editor: F. M. Hetrick, College Park, Maryland, USA
Chen SN, Kou GH, Hedrick RP, Fryer JL (1985) The occurrence of viral infections of fish in Taiwan. In: Ellis AE (ed) Fish and shellfish pathology. Academic Press Inc, New York, p 313-319

Dixon PF, Hill BJ (1984) Inactivation of infectious pancreatic necrosis virus for vaccine use. J Fish Dis 6:399-410

Hattenberger-Baudouy AM, Danton M. Merle G, Torchy C, de Kinkelin P (1989) Serological evidence for infectious hematopoietic necrosis in rainbow trout from an outbreak in France. J Aquat Anım Health 1:126-134

Hsu YL, Leong JC (1985) A comparison of detection methods for infectious hematopoietic necrosis virus. J Fish Dis 8: $1-12$

Huang CM, Chien MS, Landolt ML, Winton JR (1994) Characerization of the infectious hematopoietic necrosis virus glycoprotein using neutralizing monoclonal antibodies. Dis Aquat Org 18:29-35

Jørgensen PEV, Olesen NJ, Lorenzen N, Winton JR, Ristow S (1991) Infectious hematopoietic necrosis virus: detection of humoral antibodies in rainbow trout by plaque neutralization, immunofluorescence, and enzyme-linked immunosorbent assays. J Aquat Anim Health 3:100-108

Mulcahy DM, Pascho RJ (1985) Vertical transmission of infectious hematopoietic necrosis virus in sockeye salmon (Oncorhynchus nerka): isolation of virus from dead eggs and fry. J Fish Dis 8:393-396

Nicholson BL (1989) Fish cell culture: an update. In: Nicholson BL (ed) Advances in cell culture, Vol 7 Academic Press Inc, New York. p 1-13

Nicholson BL (1993) Use of monoclonal antibodies in identif1cation and characterization of fish viruses. Annu Rev Fish Dis 3:241-257

Sano T (1976) Viral diseases of cultured fishes in Japan. Fish Pathol 10:221-226

Way K, Dixon PF (1988) Rapid detection of VHS and IHN viruses by the enzyme-linked immunosorbent assay, ELISA. J Appl Ichthyol 4:182-189

Wolf K (1988) Fish viruses and fish viral diseases. Cornell University Press, Ithaca, NY

Manuscript first received: January 31, 1996

Revised version accepted: July 3, 1996 